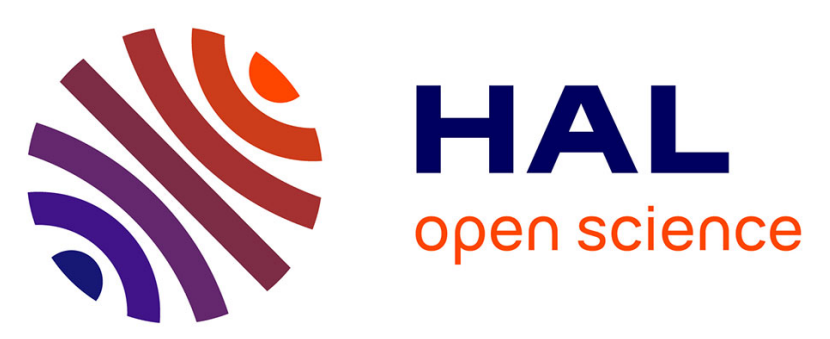

\title{
Introduction of Clean Energy Vehicles in Poland Under Energy Security Constraints
}

Kamila Romejko, Masaru Nakano

\section{To cite this version:}

Kamila Romejko, Masaru Nakano. Introduction of Clean Energy Vehicles in Poland Under Energy Security Constraints. IFIP International Conference on Advances in Production Management Systems (APMS), Sep 2015, Tokyo, Japan. pp.343-352, 10.1007/978-3-319-22759-7_40 . hal-01431115

\section{HAL Id: hal-01431115 \\ https://hal.inria.fr/hal-01431115}

Submitted on 10 Jan 2017

HAL is a multi-disciplinary open access archive for the deposit and dissemination of scientific research documents, whether they are published or not. The documents may come from teaching and research institutions in France or abroad, or from public or private research centers.
L'archive ouverte pluridisciplinaire HAL, est destinée au dépôt et à la diffusion de documents scientifiques de niveau recherche, publiés ou non, émanant des établissements d'enseignement et de recherche français ou étrangers, des laboratoires publics ou privés.

\section{(c)(1)}

Distributed under a Creative Commons Attribution| 4.0 International License 


\title{
Introduction of Clean Energy Vehicles in Poland under energy security constraints
}

\author{
Kamila Romejko, Masaru Nakano \\ The Graduate School of System Design and Management, Keio University Kyosei Building, 4- \\ 1-1, Hiyoshi, Kohoku-ku, Yokohama, Kanagawa, 223-8526, Japan \\ kamilarr@keio.jp, nakano@sdm.keio.ac.jp
}

\begin{abstract}
Clean Energy Vehicles (CEVs) are gradually growing in popularity worldwide due to environmental characteristics. However, they are slowly attracting attention in the world due to high prices and infrastructural constraints. Over the past century there has been a dramatic increase in usage of energy, especially in the transportation industry. The purpose of this study is to analyse the development of the CEVs market in Poland while considering economic and energy security issues. The objective of the study is to create a future scenario of automotive portfolio in 2030 that will sustain energy security. The first step is to qualitatively investigate the problem by carrying out interviews with the pundits. The second step is a quantitative analysis. This study adopts an optimization technique to uncover an optimal portfolio of the CEVs and focus on Polish market.
\end{abstract}

Keywords: Energy security, Transportation, Clean Energy Vehicles, Oil Dependency, Gas Dependency, Vehicle Portfolio

\section{Introduction}

Along with increasing crude oil prices, a high pressure is put all over the world for the proliferation of Clean Energy Vehicles (CEVs), to reduce not only CO2 emissions, but also energy consumption in the automotive sector to provide apt energy security. The transportation sector accounts for approximately $20 \%$ of total worldwide energy consumption [1].

Despite abundance of the choice, Poland is still lagging behind with sales of CEVs. In 2011, there were only 897 hybrid vehicles registered [2]. When it comes to ensuring energy security, the situation does not look bright too. $96.8 \%$ of Poland's crude oil consumption and $69.4 \%$ of Poland's natural gas consumption are being satisfied from import supplies [3]. Transport sector itself is responsible for over $60 \%$ of crude oil consumption in Poland [4].

There have been plenty of studies carried out on the CEVs portfolio and future energy trends. The scopes of them were gathered in the Table 1 . The analysis of conventional studies shows that either the studies are focused only on one type of the CEVs or do not take into account buses or trucks. Only the paper [5] incorporated energy security as well as green house gas, written in Japanese. The research incorpo- 
rated data concerning bus and trucks. The paper, however, does include oil restriction, but is not taking into consideration gas restrictions.

Table 1 Conventional studies on CEVs

\begin{tabular}{llllll} 
Research & $\begin{array}{l}\text { Passenger } \\
\text { Vehicle }\end{array}$ & $\begin{array}{l}\text { All types } \\
\text { of CEV }\end{array}$ & $\begin{array}{l}\text { Oil } \\
\text { restriction }\end{array}$ & $\begin{array}{l}\text { Gas } \\
\text { restriction }\end{array}$ & $\begin{array}{l}\text { Truck } \\
\text { \& Bus }\end{array}$ \\
\hline IEA (2012) & $\mathrm{X}$ & $\mathrm{X}$ & $\mathrm{X}$ & & \\
Y. Arimori (2012) & $\mathrm{X}$ & $\mathrm{X}$ & $\mathrm{X}$ & & $\mathrm{X}$ \\
H.Choi (2010) & & & $\mathrm{X}$ & & \\
S. T. Chua (2013) & & & $\mathrm{X}$ & & \\
This research & $\mathrm{X}$ & & $\mathrm{X}$ & $\mathrm{X}$ & $\mathrm{X}$ \\
\hline
\end{tabular}

In the case of European countries like Poland, gas is an important source of energy, also in terms of automotive usage. In line with the above, the originality of this study is, that it includes gas security restrictions due to huge LPG market in Poland and possible proliferation of CNG vehicles in the future.

The goal of this research is to forecast the share or sales of CEVs according to an optimisation model for passenger vehicles, trucks and buses, considering 8 types of vehicle engines (powertrains): GV (Gasoline Vehicle), DV (Diesel Vehicle), HEV (Hybrid Electric Vehicle), DHV (Diesel Hybrid Vehicle), CNG (Compressed Natural Gas Vehicle), FCV (Fuel Cell Vehicle), EV (Electric Vehicle), LPG (Liquefied Petroleum Gas Vehicle) till 2030, while considering energy security issues in Poland as a case. Firstly, interviews with the pundits are carried out and later optimisation model is created in order to provide a base for decisions for new governmental policies and planning for companies working in the automotive industry. Automotive portfolios considering energy security issues in 2030 are created.

Section 2 describes the automotive and energy sector in Poland. The evaluation model is explained in Section 3. Constraints of the model are provided with an outline of an optimisation model, governmental targets are being set and the objective function of this research is presented. The results are demonstrated in Section 4. In the last part, the deliverables of this research are summarized and future subjects are also identified.

\section{Analysis of the Automotive and Energy Sector in Poland}

\subsection{Current Status of the Automotive Industry in Poland}

Polish government has recently showed first signs of interest towards CEVs and is considering this area as a future investment.. However, the situation for the importation of oil and gas is undoubtedly different than it is for coal. That is why Poland should treat the introduction of CEVs as an opportunity to become more independent from fuel imports, and as a way of spurring automotive industry in Poland. 


\subsection{Current Status of the Energy Sector in Poland}

Energy security issues are becoming another preeminent topic, especially after considering recent political developments in the Russian-Ukrainian dispute. Energy resources security is a crucial concern for a developing country. Energy security definitions have already been researched by plenty of pundits.

\section{Energy Use in The Transportation Sector}

The transport Sector is responsible for $64 \%$ of the crude oil consumption in Poland. When it comes to the gas consumption by the sector, $37 \%$ of total demand is consumed by industry, followed by residential use, and transportation [6]. In the time period between 1998 and 2012, demand for diesel grew by $70 \%$, and demand for LPG almost doubled. Currently, diesel is used in the largest quantities, followed by gasoline and LPG. Trucks are using the largest amount of diesel fuel. However, 56\% of total consumption is due to passenger vehicles [7].

\section{Influence of Russian-Ukrainian dispute on energy security}

Dependency on Russian energy supplies is often cited as a threat to Central European energy security. Imports to the EU from Russia are dominated by crude oil and gas. Cuts of gas importation have happened before, e.g in 2009 during UkrainianRussian gas dispute [8]. Moreover, Russia introduced a ban on imports of fruits and vegetables from Poland in 2014, depriving it of a major export market. It is estimated, that the cost of this embargo stands at $0.6 \%$ of GDP by the end of 2014 [9]. Along with increasing crude oil prices and unstable political situation in Ukraine, the Polish citizens and government have opened their eyes, and urge securing energy safety issues.

\section{$3 \quad$ Methodology}

The research concerns policy, market and data study, which is why both qualitative methods and quantitative methods. The study is conducted in line with the Fig.1.

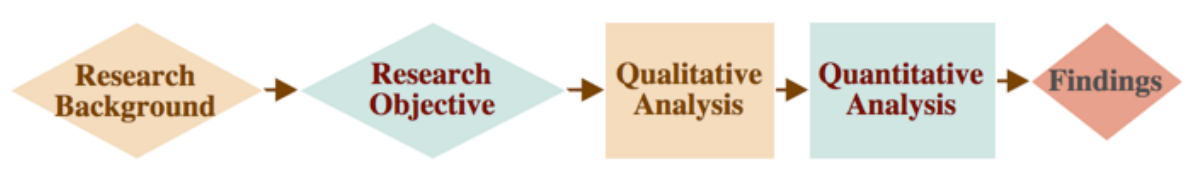

Fig. 1 Research process

In the beginning of the study, intelligence gathering was conducted and research objective and questions were formulated: Why CEVs are not popular in Poland and what policy should be introduced to change the situation? The purpose of Qualitative Analysis is to find causes that prevent popularity of CEVs. In this part stakeholder analysis and interviews with pundits are being conducted. Qualitative findings were used and combined in quantitative analysis in order to analyse the development of the 
CEV market in Poland till 2030. The purpose of Quantitative Analysis is to design optimal future vehicle portfolio.

\subsection{Qualitative Analysis}

In order to achieve economic goals, a qualitative analysis of both the automotive and energy sector in Poland was carried out. Firstly, stakeholder analysis was carried out by using Customer Value Chain Analysis (CVCA) [10]. Later interviews with stakeholders were conducted. By using this methodology research questions were verified.

\subsection{Quantitative Analysis}

Qualitative analysis is computed from a systematic approach, including two parts: economical efficiency, oil and gas dependency rate. Therefore, the prior mentioned model defines economical efficiency of the vehicle portfolio while considering oil and gas dependency rates. Based on the above, the key map of a CEV portfolio optimisation model has been built, which can be seen in the Fig. 2. Three categories of vehicles are considered: passenger vehicles, buses and trucks. Moreover, 8 types of vehicles are taken into consideration based on powertrain variations (GV, DV, HEV, DHV, CNG, FCV, EV and LPG). The following model takes as input three groups of data: restriction values (gas and oil rates), vehicles characteristics (vehicle price, fuel consumption, etc.) and other preconditions (energy price, etc.). This data is input into the optimisation model and the output is the optimal solution of the volume of new vehicle registrations for every CEV. The methodology was developed at the Business Engineering LAB at KEIO SDM, Graduate School of System Design and Management, and it has not been published in an English-journal before.

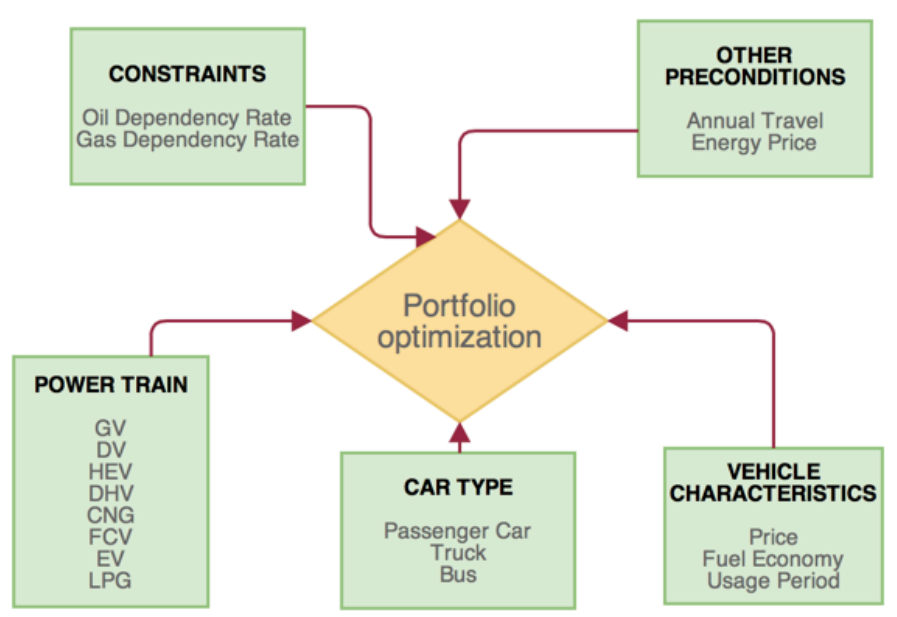

Fig. 2 Key map of a proposed CEVs portfolio optimisation model 
The objective function is directly connected with the cost - economic efficiency. CEV system cost is formulated as follows (1): The right-hand side of formula expresses three costs using the volume of new vehicle registrations, which is designed as a variable. The first clause expresses fuel cost, the second clause expresses vehicles cost, and the third clause expresses infrastructure cost. The optimal solution at the time of minimizing this CEV system cost is computed as follows in EQ. (1).

$$
\begin{aligned}
& \min f_{k}\left(x_{j k}\right) \\
& f_{k}\left(x_{j k}\right)=\sum_{i} \sum_{j} S_{j k}\left(x_{j k}\right) A_{j} F_{j k} E_{i k}+\sum_{j} x_{j k} V_{j k}+\sum_{j} \frac{x_{j k} T_{j}}{I} \\
& S_{j k}\left(x_{j k}\right)=x_{j k}+S_{j k-1}-\frac{S_{j k-1}}{U_{j}}
\end{aligned}
$$

$i$ : Type of energy [Gasoline, light oil, natural gas, hydrogen, electricity]

$j$ : Vehicle type [passenger vehicle (GV), passenger vehicle (DV), passenger vehicle (HEV), passenger vehicle (DHV), passenger vehicle (CNG), passenger vehicle (FCV), passenger vehicle (EV), passenger vehicle (LPG), truck (GV), truck (DV), truck (HEV), truck (DHV), truck $(\mathrm{CNG})$, truck (FCV), truck (EV), truck (LPG), bus (GV), bus (DV), bus (HEV), bus (DHV), bus (CNG), bus (FCV), bus (EV), bus (LPG)]

$k$ : Object year [2012-2030]

$f_{k}: k$ yearly CEV system cost [PLN]

$x_{j k}$ : Volume of new vehicle registrations in $k$ years of the vehicle type $j$ [Unit]

$S_{j k}$ : The number of possession in k years of the vehicle type $j$ [Unit]

$U_{j}$ : Average tenure of use of the vehicle type $j$ [Year]

$F_{j k}$ : Possession average real run fuel consumption in $k$ years of the vehicle type $j[\mathrm{MJ} / \mathrm{km}]$

$A_{j}$ : Annual average mileage of the vehicle type $j[\mathrm{~km}]$

$E_{i k}$ : The energy price in $k$ years of the energy $i[\mathrm{PLN} / \mathrm{MJ}]$

$V_{j k}$ : Vehicles price in $k$ years of the vehicle type $j$ [PLN/stand]

$T_{j}$ : Infrastructure price of the vehicle type $j[\mathrm{PLN} / \mathrm{Spot}]$

$I$ : The ratio of the number of $\mathrm{CEV}$ possession to the required number of infrastructures

Gas and oil dependency rate restriction are formulised in formulas (2) and (3). The denominator of the right-hand side of a formula (2) expresses total energy expenditure, and the numerator expresses the total oil consumption, following formula (3) provides the total gas consumption.

$$
\begin{gathered}
D_{k} \geq \frac{\sum_{j} S_{j k}\left(x_{j k}\right) A_{j}\left(O_{j k}+F_{j k} G_{j k}\right)}{\sum_{j} S_{j k}\left(x_{j k}\right) A_{j} F_{j k}} \\
H_{k} \geq \frac{\sum_{j} S_{j k}\left(x_{j k}\right) A_{j}\left(O_{j k}+F_{j k} M_{j k}\right)}{\sum_{j} S_{j k}\left(x_{j k}\right) A_{j} F_{j k}}
\end{gathered}
$$

$D_{k}: k$ year oil dependency rate desired value $\left(D_{k} \in[0,1]\right)$ 
$\mathrm{O}_{\mathrm{jk}}$ : They are gasoline and a diesel amount consumption per [in $k$ years of the vehicle type $j$ ] 1$\mathrm{km} \operatorname{run}[\mathrm{MJ} / \mathrm{km}]$

$G_{k}$ : Rate of the oil power, $\left(G_{k} \in[0,1]\right)$

$G_{j k}: k$ year power supply composition

$H_{k}: k$ year gas dependency rate desired value $\left(H_{k} \in[0,1]\right)$

$O_{j k}$ : Amount of gas consumption per [in $k$ years of the vehicle type $\left.j\right] 1-\mathrm{km}$ run. $[\mathrm{MJ} / \mathrm{km}]$

Rate $\left(M_{k} \in[0,1]\right)$, gas dependency in electricity of the oil fire power in $G_{j k}: k$ year power supply composition

There have been several changes done to the model. First of all, the originality of this study is that gas security restrictions are included. Secondly, CNG vehicles are being researched instead of NGV. LPG vehicles are also included in this study and where not taken into consideration. Furthermore Energy and vehicle price is calculated based on estimations for Polish market and not global prices.

\section{$4 \quad$ Results and discussion}

\subsection{Stakeholders}

Fig. 3 presents the analysis of stakeholders and their relationship that was carried out with CVCA. Four main stakeholders were identified: consumer, car manufacturer, government and energy company. The most important stakeholder is government. It receives TAX from other stakeholders and its role is to provide subsidies and policy support.

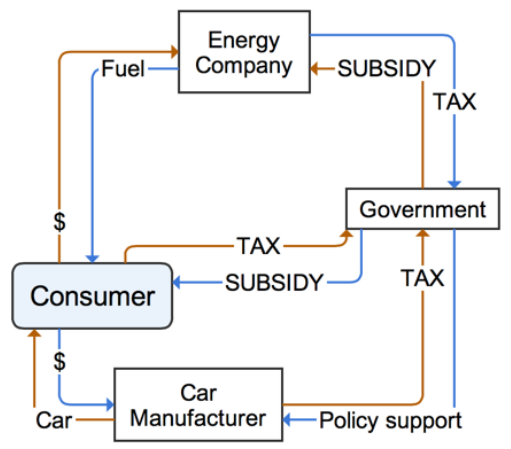

Fig. 3 CVCA analysis

\subsection{Interview results}

The first interviewee is an expert from Department of Innovation and Industry from Ministry of Economy. He believes that when it comes to terms with governmental stakeholder it is the Ministry of Finance is reluctant on creating an incentive system, rejecting proposals in order to protect the yearly budget. Forgetting that those 
aids can bring income from other sources. The interviewee believes that change in policy is essential to change the situation. His recommendations include i.a. establishing new scrap incentive system based on the previous experience in Germany. Unless the government introduces aid for customers to buy CEVs, the number of sales will still stand at a minor level. Furthermore, new tax system is crucial to change the situation. The next stakeholders considered in this interview are automakers. Automakers aim and collaborate with local government, which is more willing to achieve aforementioned goals. Low sales means less investment from other countries and less people employed. Following, the statement on consumers was build. The pundit confirmed the fact that individuals do not wish to buy CEVs because of high prices and prefer to buy used cars, or just cheaper makes. Confusing car tax policy means that buyers postpone their decision on a purchase of a new vehicle.

Next interviewee is Sales Managing Director in Automotive Company in Poland. He stated that government and its policy discourage buyers from purchasing new cars, favoring more affordable non-efficient ones. Furthermore, European policy created an easy access to affordable used cars from Germany. Poles are not concerned with environmental issues. There is low affordability of CEVs in Poland. Consumers tend to buy cheaper, not environmental friendly cars. Polish people have very little knowledge of CEVs. There is a need to educate consumers, giving them a fresh and realistic view of CEVs. Since people travel for long distances and use cars for many years, CEVs seem like a good investment if people know that they should take into consideration life cycle cost of a vehicle and not only the initial cost. From the pundit point of view automakers expect a higher volume of vehicle sales in Poland. High demand on new vehicles, low turnover of employees and cost of employees are the factors that influence decision on establishing a new vehicle plant. Moreover, the drop in price, could give customers incentive to purchase a CEV. The tables 2 and 3 sums up the results of interviews with stakeholders.

Table 2 Government view on CEVs problems

\begin{tabular}{c|c|c}
\hline Government & Issues & Possible measures \\
\hline Government & Protect budget & New scrap incentive system \\
\hline Automakers & $\begin{array}{c}\text { Low sales = low investment; poor collabora- } \\
\text { tion with government }\end{array}$ & $\begin{array}{c}\text { Collaboration with local } \\
\text { government }\end{array}$ \\
\hline Consumers & $\begin{array}{c}\text { High price of CEVs, purchase of used cars; } \\
\text { Confusing tax policy }\end{array}$ & Tax reduction incentives \\
\hline
\end{tabular}

Table 3 Automakers view on CEVs problems

\begin{tabular}{c|c|c}
\hline Automakers & Issues & Possible measures \\
\hline Government & $\begin{array}{c}\text { Easy access to used cars from Germany } \\
\text { Policy and rules discourage purchase of new car }\end{array}$ & CEVs subsidies \\
\hline Automakers & A higher volume of sales is expected & $\begin{array}{c}\text { Higher vehicle demand; } \\
\text { Proximity of factories; }\end{array}$ \\
\hline & $\begin{array}{c}\text { Low affordability of CEVs; } \\
\text { Clients not concerned with environmental issues; } \\
\text { Consumers using non-efficient diesel engines } \\
\text { Little knowledge on CEVs; }\end{array}$ & $\begin{array}{c}\text { CEVs price drop; } \\
\text { Education of clients }\end{array}$ \\
\hline
\end{tabular}


Furthermore, Prius price analysis was conducted as shown in Table 4 and was approved by the second interviewee. The results prove that the premium consists most of the taxes applied by Polish government and not market premium of a Japanese producer. The parameter 1.0 amounts to $2170000 \mathrm{YPY}$.

Table 4 Prius price analysis

\begin{tabular}{ll} 
Item & Value \\
\hline Market price of Prius in Japan & 1.00 \\
Cost of Prius in Japan without TAX (8\%) & $\mathbf{0 . 9 5}$ \\
Transport cost & 0.01 \\
Customs - 10\% & 1.06 \\
Excise TAX - 18,6\% & 1.25 \\
TAX in Poland - 23\% & 1.54 \\
Cost of Prius in Poland according to calculations & 1.54 \\
Market price of Prius in Poland & $\mathbf{1 . 5 7}$ \\
Market price of Prius in USA & 1.13 \\
\hline
\end{tabular}

All of the above interviews provided insight into Polish automotive sector and confirmed some of the issues that were found during the research.

\subsection{Experimental results}

During calculation of the optimal portfolio it became clear that both oil and gas restriction rates are not independent. Both of goals cannot be reached simultaneously if the minimisation of total system cost is taken into consideration. However, it was forecasted that gas consumption will rise anyway in years to come, and there are possibilities of shale gas in Poland. Therefore it was decided that the gas spending should just be minimised. Ratio possession numbers of passenger vehicles in 2012 and 2030 are represented below in Fig.4.

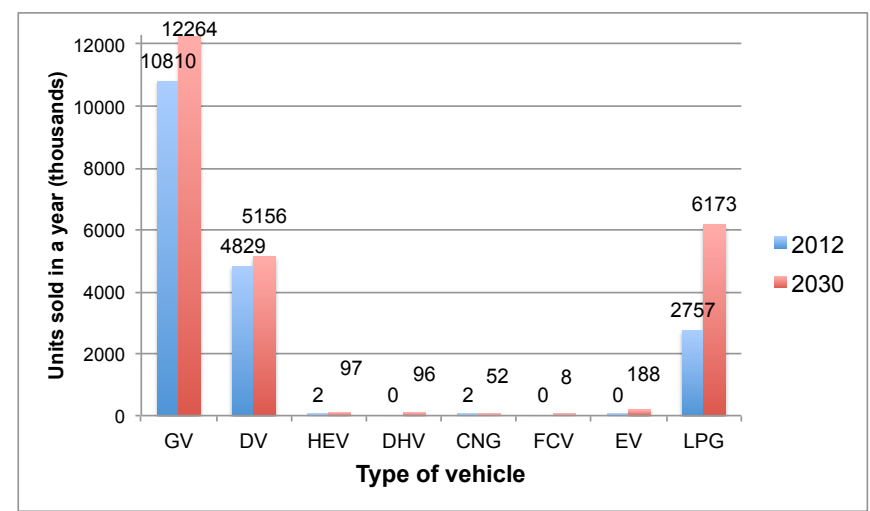

Fig. 4 Passenger vehicle portfolio in 2012 and 2030 [units] 
In passenger vehicles category HEVs, DHVs and EVs have attracted attention in 2030. Those were the types of vehicles, which gained the most within the time period. HEV seem to be a perfect-match solution for the Polish market, since people tend to travel long distances and EV could be popular in metropolises. In bus category there were changes recorded in sales of CEV, however bus sales are not significant.

If the gas restrictions are omitted, the transition from regular vehicles into $\mathrm{CEV}$ is slower and spread of them is low. Even though, the CEVs increase in total vehicle park seems insignificant, it is important to take into consideration that in 2012, $1.5 \mathrm{mil}$ used vehicles were sold, but only around 300,000 new ones were sold.

\section{Conclusions}

Concerns surrounding energy security and climate change, along with improvements in technology have spurred an interest in clean energy vehicles. This paper has examined both the automotive and energy sector in Poland. With the present and forecasted future energy mix in Poland, CEVs are clearly much more favourable when compared with GVs and DVs. This study was designed to determine the optimal portfolio of CEVs in Poland until 2030.

One of the more significant findings to emerge from this study is that Polish society requires full portfolio of clean energy vehicles and fuel options to achieve both economic and energy security objectives. Those goals cannot be reached by introducing only one type of CEV alone. HEVs might be treated as an intermediate step before introduction of EVs, FCVs. Moreover, this research can serve as a base for future studies of governmental policies towards CEVs in Poland. The results of the study may support policy makers while making their decision on applying policy to increase vehicle sales in Poland.

\section{References}

[1] International Energy Agency (IEA), Energy Technology Perspectives - 2012, IEA Publications, (2012)

[2] Polish Automotive Industry Association, Automotive Industry Yearbook 2013, (2013) http://www.pzpm.org.pl/pl/content/download/5452/24659/file/PZPM_Raport_2013.pdf 15.01.2015 [Polish]

[3] International Energy Agency (IEA). Energy balance for Poland - 2009, (2012), http://www.iea.org/stats/balancetable.asp?COUNTRY_CODE=PL, 17.02.2015

[4] International Energy Agency (IEA), Energy policies of IEA countries: Poland - 2011, (2013)

[5] Y. Arimori, M. Nakano, Portfolio Optimization for Clean Energy Vehicles in Japan, No.78, Vol.291, Pages 2571-2582, (2012), [Japanese], http://dx.doi.org/10.1016/j.erss.2014.08.008.

[6] International Energy Agency (IEA), Oil \& Gas Security: Poland - 2011, (2011)

[7] Z. Chlopek, P. Pawlak., J. Waskiewicz, Experts forecast the demand for energy carriers for vehicle fleet in Poland in 2030, ITS 6243/ZBE, (2011)

[8] The Russo-Ukrainian gas dispute of January 2009: a comprehensive assessment, Oxford Institute for Energy Studies, Pages 53-55, (2009)

[9] BBC online, Russia bans Polish fruit and veg amid sanctions war, http://www.bbc.com/news/worldeurope-28603140, 10.01.2015

[10] K. Donaldson, K. Ishii, S. Sheppard, Customer Value Chain Analysis, Research in Engineering Design, Vol.16, 174-183, (2006) 